\title{
Indirect Spectrophotometric Determination of Oxymetazoline Hydrochloride
}

\author{
Nabeel S. Othman \\ Department of Chemistry \\ College of Science \\ University of Mosul \\ nsn20002004@yahoo.com
}

Sahar A. Fathe

sahar09a@yahoo.com

(Received 7/ 5/2012;Accepted 18/7/2012)

\begin{abstract}
A simple and sensitive spectrophotometric method for the quantitative determination of trace amounts of oxymetazoline hydrochloride (OMZ) was developed .The method based on the reaction of (OMZ) with Fe(III) in acidic medium. The librated Fe(II) coupled with potassium ferricyanide, the reaction needs heating for 25 minutes at $50^{\circ} \mathrm{C}$, to form Prussian blue which is more stable by adding $1 \mathrm{ml}$ of $1 \%$ ethylendiaminetetraacetic acid. The maximum absorption of the product was measured at $766 \mathrm{~nm}$. Beer's law is obeyed in the concentration range $5-125 \mu \mathrm{g} / 10 \mathrm{ml}$ with a molar absorptivity of $5.07 \times 10^{4} 1 . \mathrm{mol}^{-1} . \mathrm{cm}^{-1}$, with a relative error of +1.74 to $+2.34 \%$ and a relative standard deviation (RSD\%) of the of \pm 1.272 to $\pm 1.982 \%$.The method was applied successfully for the assay of OMZ in pharmaceutical preparation.
\end{abstract}

Keywords: Oxymetazoline hydrochloride; oxidation-reduction; spectrophotometry.

\section{القير الليف غير المبلشر لهيروكلوربد الاوكسمينازولين}

\section{الملغص}

مُ قطوير طريقة طفية بسيطة ومسلسة للقدير الكمي لمميلت نزرة من هيدروكلوريد الاوكسي

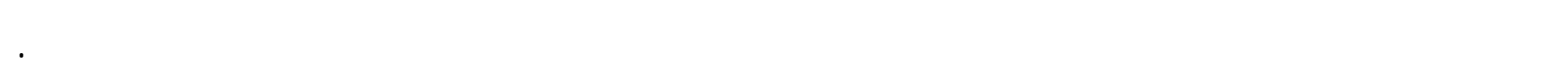

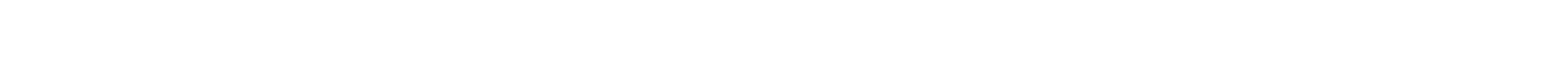

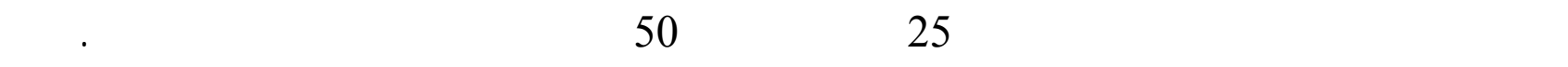

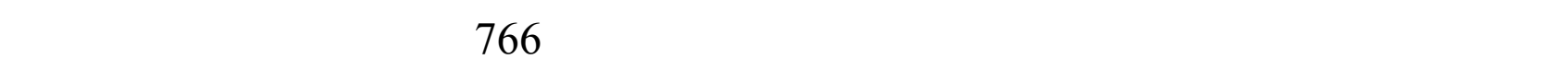
ثنائي الامين رباعي حلمض الخليك (1\%). كانت حدود ظبيق قانون بيير في مدى التركيزمن 5 إلى 125

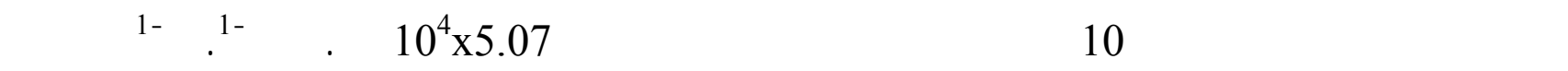

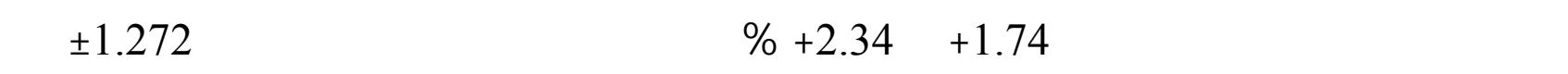

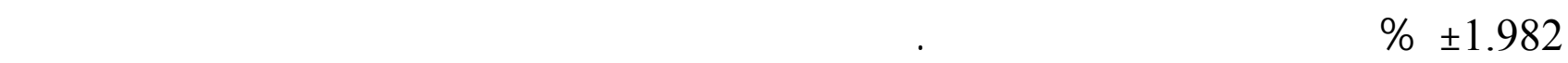
ميتازولين في مستحضر دوائي. 
INTRODUCTION

Oxymetazoline hydrochloride(OMZ) is 4-tert- butyl 2,6-dimethyl -3-hydroxy -benzylimidazoline hydrochloride (USP, 2009) (I).

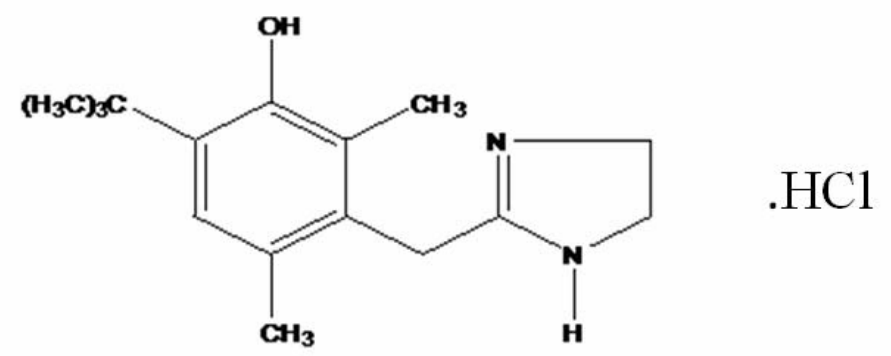

(I) Oxymetazoline hydrochloride

$$
\text { M.wt. }=296.8 \text { g.mol }{ }^{-1}
$$

OMZ is available as a topical decongestant in nasal spray, it is also used to treat epistaxis and eye redness (Wikipedia, 2008 ).

Different methods have been used for the spectrophotometric determination of oxymetazoline hydrochloride.

Different reagents have been used in the determination OMZ as a pure and in dosage forms such as: sodium cobalti nitrite in acetic acid medium (Shingbal et al., 1983), 2,6dichloroquinonchlorimide the method based on the formation of a coloured oxidative coupling product (Sankar et al., 1987), Fe (III) and 2,4,6-tris(2-pyridyl)-5-triazine (Sankar et.al,1988). The formation of ferrion complex which is measured at $510 \mathrm{~nm}$. is produced by oxidation - reduction reaction between OMZ and ferric ion, (AL-Sabha and Rashed, 2011), 4-Aminoantipyrine in presence of potassium periodate in oxidative coupling reaction (Zakaria,2011), 3,5-dinitrosalicylicacid (AL-Neaimy, 2006).

The construction and analytical application of plastic membrane electrode (ion selective electrode) for the determination of OMZ was applied (Issa and Zayed, 2004), also a flow injection analysis of OMZ with inhibited chemiluminscent detection (Garcia et al., 2004; Wang et al., 2009)was also reported.The chromatographic method, high performance liquid chromatography technique has been used in the determination of OMZ (Sudsakorn et al., 2006; Hong, 2009; Hoffmaann, 1989; Hayes, 1995; Stanisz and Nowinki, 2000).

The British pharmacopoeia reported a potentiometric method using perchloric acid solution for the determination of OMZ (British Pharmacopeia, 2007)

The objective of the investigation reported in this paper is to evaluate a sensitive and accurate method for the assay of oxymetazoline in a pure form or in dosage forms. The method was based on the oxidation of OMZ using Fe (III) in acidic medium and the librated Fe (II) which subsequently complexes with potassium ferricyanide to form the Prussian blue complex. 


\section{Instruments}

\section{EXPERIMENTAL}

Spectrophotometric measurements are performed using Shimadzu UV-160 UVVisible recording spectrophotometer using $1.0 \mathrm{~cm}$ quartz cells. The $\mathrm{pH}$ measurements are performed by using $\mathrm{pH}$ meter type HANNA $211 \mathrm{pH}$-ion meter. Waterbath (Memmert, Germany) has also been used.

\section{Reagents}

All chemicals used in this investigation are of analytical grade. Oxymetazoline hydrochloride standard material was provided from state company for Drug Industries and Medical Appliance (N.D.I), Ninavah-Iraq.

\section{Working OMZ solution ( $50 \mu \mathrm{g} \cdot \mathrm{ml}^{-1}$ )}

This solution is prepared by dissolving $0.005 \mathrm{~g}$ of $\mathrm{OMZ}$ in distilled water and the volume is completed to the mark with distilled water in $100 \mathrm{ml}$ volumetric flask.

\section{Ferric chloride solution, $0.1 \%$}

This solution is prepared by dissolving $0.1 \mathrm{~g}$ of ferric chloride (Fluka) in distilled water and completed with distilled water to the mark in a $100 \mathrm{ml}$ volumetric flask.

\section{Potassium ferricyanide ,0.1\%}

This solution is prepared by dissolving $0.1 \mathrm{~g}$ of potassium ferricyanide in distilled water and completed with distilled water to the mark in a $100 \mathrm{ml}$ volumetric flask .

\section{Recommended procedure and calibration curve}

To a series of $10 \mathrm{ml}$ calibrated flasks, 0.1 to $2.5 \mathrm{ml}$ of $50 \mu \mathrm{g} / \mathrm{ml} \mathrm{OMZ} \mathrm{solution} \mathrm{were}$ added followed by the addition of $3 \mathrm{ml}$ of potassium ferricyaninde $(0.1 \%), 3 \mathrm{ml}$ of $\mathrm{Fe}$ (III) $(0.1 \%)$ and $0.5 \mathrm{ml}(1 \mathrm{M})$ acetic acid were added. Then the solution stood for 25 minutes in water bath adjusted at $50^{\circ} \mathrm{C}$, then $1 \mathrm{ml}$ of $\operatorname{EDTA}(1 \%)$ was added and diluted to the mark with distilled water. The absorbance was measured at $766 \mathrm{~nm}$ against the reagent blank.

The calibration graph is linear over the concentration range of 5-125 $\mu \mathrm{g} / 10 \mathrm{ml}$ while higher concentrations show a negative deviation from Beer's law (Fig. 1), the apparent molar absorptivity referred to OMZ has been found to be $5.07 \times 10^{4} 1 . \mathrm{mol}^{-1} . \mathrm{cm}^{-1}$

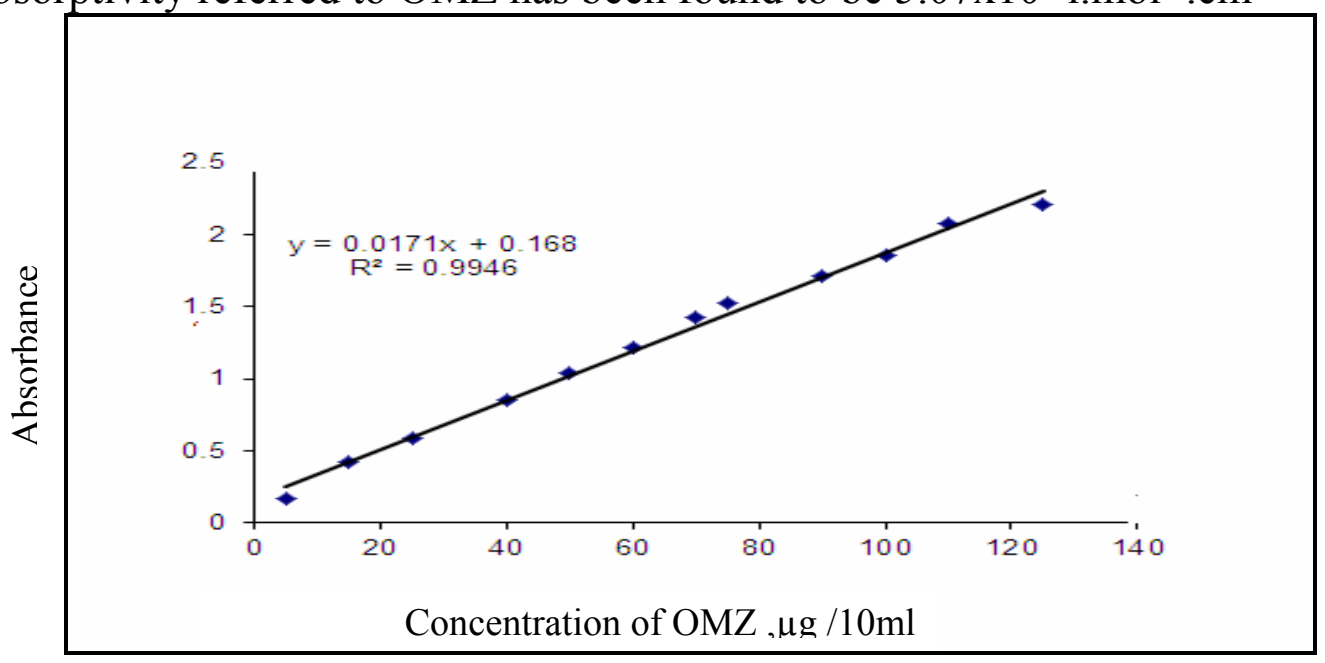

Fig.1: Calibration graph for OMZ determination using the proposed method. 


\section{Determination of $\mathrm{OMZ}$ in nasal drop}

The contents of 3 containers of Oxymet drops were mixed well, a $5 \mathrm{ml}$ which is equivalent to $0.0025 \mathrm{~g} \mathrm{OMZ}$ was diluted to $50 \mathrm{ml}$ with distilled water in a volumetric flask. A suitable aliquot of drug solution was analyzed as described in the recommended procedure.

\section{RESULTS AND DISCUSSION}

The effect of various variables on the color development of $12.5-100 \mu \mathrm{g} O M Z / 10 \mathrm{ml}$ reacted with ferric chloride $(0.1 \%)$ and potassium ferricyanide reagent $(0.1 \%)$ in acidic medium was tested to establish the optimum conditions for the determination of OMZ by Prussian blue complex formation reaction.

\section{Effect of the amount of ferric chloride}

Increasing volumes of ferric chloride solution $(0.1 \%)$ were added to the standard amounts of $\mathrm{OMZ}$, the results indicated that $3 \mathrm{ml}$ of ferric chloride solution gave the highest intensity of colored product at $720 \mathrm{~nm}$, and this volume was considered as an optimum (Table 1).

Table 1: Effect of ferric chloride amount on absorbance

\begin{tabular}{|c|c|c|c|c|c|c|}
\hline \multirow{2}{*}{$\begin{array}{c}\text { ml of } \\
\mathrm{Fe}^{+3}(0.1 \%)\end{array}$} & \multicolumn{6}{|c|}{ Absorbance/ $\mu \mathrm{g}$ OMZ used } \\
\hline & 12.5 & 25 & 50 & 75 & 100 & $\mathrm{R}^{2}$ \\
\hline 1 & 0.065 & 0.112 & 0.214 & 0.280 & 0.66 & 0.9951 \\
\hline 2 & 0.073 & 0.139 & 0.260 & 0.377 & 0.473 & 0.9964 \\
\hline 3 & 0.078 & 0.146 & 0.281 & 0.394 & 0.550 & 0.9974 \\
\hline 4 & 0.057 & 0.125 & 0.242 & 0.377 & 0.506 & 0.9993 \\
\hline
\end{tabular}

\section{Effect of the amount of potassium ferricyanide}

Various volumes of potassium ferricyanide solution $(\mathrm{R})(0.1 \%)$ were added. The results indicated that using $3 \mathrm{ml}$ of this solution gave maximum absorbance of colored product at $720 \mathrm{~nm}$, and this volume was recommended in the subsequent experiments (Table 2).

Table 2: Effect of potassium ferricyanide amount on absorbance.

\begin{tabular}{|c|c|c|c|c|c|c|}
\hline ml of & \multicolumn{7}{|c|}{ Absorbance/ $\boldsymbol{\mu g}$ OMZ used } \\
\cline { 2 - 7 } $\mathbf{R ( 0 . 1 \% )}$ & 12.5 & 25 & 50 & 75 & 100 & $\mathrm{R}^{2}$ \\
\hline 1 & 0.057 & 0.119 & 0.258 & 0.328 & 0.497 & 0.9995 \\
\hline 2 & 0.075 & 0.140 & 0.289 & 0.429 & 0.561 & 0.9995 \\
\hline 3 & 0.071 & 0.144 & 0.290 & 0.442 & 0.576 & 0.9996 \\
\hline 4 & 0.061 & 0.142 & 0.280 & 0.429 & 0.563 & 0.9995 \\
\hline
\end{tabular}




\section{Choice of acid and its amount}

The effect of different acids $(1 \mathrm{M})$ on the absorbance of the colored product was studied. The results indicated that $0.5 \mathrm{ml}$ of $1 \mathrm{M}$ acetic acid solution $(\mathrm{pH}=2.70$ in final dilution) was the optimum and recommended in the subsequent experiments according to the highest intensity of the colored product ( Table 3).

Table 3: Selection of acid and its optimum volume

\begin{tabular}{|l|c|c|c|c|c|c|}
\hline \multicolumn{1}{c|}{$\begin{array}{c}\text { Type of acid, } \\
\mathbf{1} \text { s solution }\end{array}$} & \multicolumn{5}{c|}{ Absorbance /ml acid used } & \multirow{2}{*}{ Final pH } \\
\cline { 2 - 7 } & 0.25 & 0.5 & 1 & 2 & 3 & \\
\hline $\mathrm{CH}_{3} \mathrm{COOH}$ & 0.304 & 0.320 & 0.280 & 0.246 & 0.259 & $2.88-2.41$ \\
\hline $\mathrm{HCl}$ & 0.193 & 0.204 & 0.115 & 0.038 & 0.024 & $1.35-0.65$ \\
\hline $\mathrm{H}_{2} \mathrm{SO}_{4}$ & 0.029 & 0.034 & 0.014 & -0.003 & -0.22 & $1.28-0.65$ \\
\hline $\mathrm{HNO}_{3}$ & 0.171 & 0.180 & 0.105 & 0.041 & 0.027 & $1.27-0.57$ \\
\hline
\end{tabular}

\section{Effect of buffer solution on absorbance and stability.}

According to the optimum $\mathrm{pH}$ found in Table 3,different types of buffers of $\mathrm{pH} 2.70$ have been tested. The results shown in Table 4 indicated that all these types of the buffer solutions used decrease the absorbance or forming a turbid solution, so that the use of a buffer solution is not recommended.

\section{Table 4: Effect of buffers}

\begin{tabular}{|r|c|c|}
\hline Buffer (2 ml used) & Absorbance & pH \\
\hline Glycine-HCl & 0.335 & 2.71 \\
\hline KHphathalate & Turbid & 2.70 \\
\hline Citric acid-NaOH & -0.027 & 2.75 \\
\hline
\end{tabular}

Note: The absorbance using acetic acid $=0.339$

\section{Effect of temperature}

The rate of reaction is observed to be slow when carried out at room temperature. However, enhanced reaction rate is observed when the reaction mixture is heated. The effect of temperature on the absorbance of the final reaction mixture is shown in (Table 5).

Table 5: Effect of temperature on absorbance

\begin{tabular}{|l|c|c|c|c|c|c|c|c|c|}
\hline Temp., ${ }^{\mathbf{0}} \mathbf{C}$ & 0 & 10 & 15 & 17 & 20 & 30 & 40 & 50 & 60 \\
\hline Absorbance & 0.255 & 0.281 & 0.292 & 0.330 & 0.338 & 0.378 & 0.481 & 0.609 & 0.590 \\
\hline
\end{tabular}

The results indicated that absorbance of the product increased with increasing temperature and heating to $50^{\circ} \mathrm{C}$ was considered as an optimum temperature.

\section{Effect of heating time}

The time needed to complete the reaction had been studied at $50^{\circ} \mathrm{C}$. The results in Table 6 showed that a maximum intensity occurred at 25 minutes heating before the dilution of the solution with distilled water to the mark. 
Table 6: Effect of heating time on absorbance

\begin{tabular}{|c|c|c|c|c|c|c|}
\hline Time, min. & 5 & 10 & 15 & 20 & 25 & 30 \\
\hline Absorbance & 0.437 & 0.509 & 0.593 & 0.669 & 0.700 & 0.700 \\
\hline
\end{tabular}

\section{Effect of surfactant}

The effect of different types of surfactants (positive, negative and neutral) on the color intensity was studied. The results showed that using Triton X-100 decreases the absorbance of the colored product whereas CPC gives a turbid solution and using SDS increases the absorbance but the solution becomes turbid after heating to $50^{\circ} \mathrm{C}$. Therefore, it has been recommended to eliminate the use of surfactants in the subsequent experiments.

\section{The stability of product}

The stability of the formed colored product was investigated under the optimum conditions for the determination of OMZ and compared with the stability of the formed colored complex after adding $1 \mathrm{ml}$ of $\mathrm{NaF}(1 \%)$ and EDTA(1\%) (Table 7).

Table 7 : Effect of time on color stability.

\begin{tabular}{|c|c|c|c|}
\hline Time/ min & $\begin{array}{c}\text { Absorbance* } \\
\text { of 50 } \mathbf{~ g g}\end{array}$ & $\begin{array}{c}\text { Absorbance** } \\
\text { (EDTA, 1\%) }\end{array}$ & $\begin{array}{c}\text { Absorbance**** } \\
\text { (NaF, 1\%) }\end{array}$ \\
\hline 0 & 0.686 & 1.143 & 0.872 \\
\hline 5 & 0.687 & 1.140 & 0.867 \\
\hline 10 & 0.683 & 1.140 & 0.869 \\
\hline 15 & 0.678 & 1.140 & 0.867 \\
\hline 20 & 0.678 & 1.140 & 0.867 \\
\hline 25 & 0.673 & 1.141 & 0.870 \\
\hline 30 & 0.672 & 1.141 & 0.876 \\
\hline 35 & 0.667 & 1.142 & 0.883 \\
\hline 40 & 0.671 & 1.142 & 0.890 \\
\hline 45 & 0.665 & 1.138 & 0.891 \\
\hline 50 & 0.658 & 1.138 & 0.894 \\
\hline 60 & 0.656 & 1.138 & 0.899 \\
\hline $\mathrm{B}_{\lambda \max }$ & 417 & 401 & 420 \\
\hline $\mathrm{S}_{\lambda \max }$ & 794 & 762 & 722 \\
\hline
\end{tabular}

*Absorbance without adding EDTA or NaF solutions

**Absorbance with 1ml EDTA solution (1\%)

***Absorbance with $1 \mathrm{ml} \mathrm{NaF}$ solution $(1 \%)$

The results indicated that adding EDTA or NaF solutions which act as masking agent for the unreacted amount of ferric ions causes an increase in the absorbance and also the resulting product becomes more stable, so that adding EDTA solution is recommend for the subsequent experiments with an optimum volume of $1 \mathrm{ml}$ (Table 8) and (Fig. 2)

Table 8: Effect of EDTA amount on stability.

\begin{tabular}{|c|c|c|c|}
\hline Ml of EDTA(1\%) & 0.5 & 1 & 2 \\
\hline Absorbance & 1.109 & 1.150 & 1.123 \\
\hline $\max ^{2} \lambda$ & 762 & 761 & 765 \\
\hline
\end{tabular}




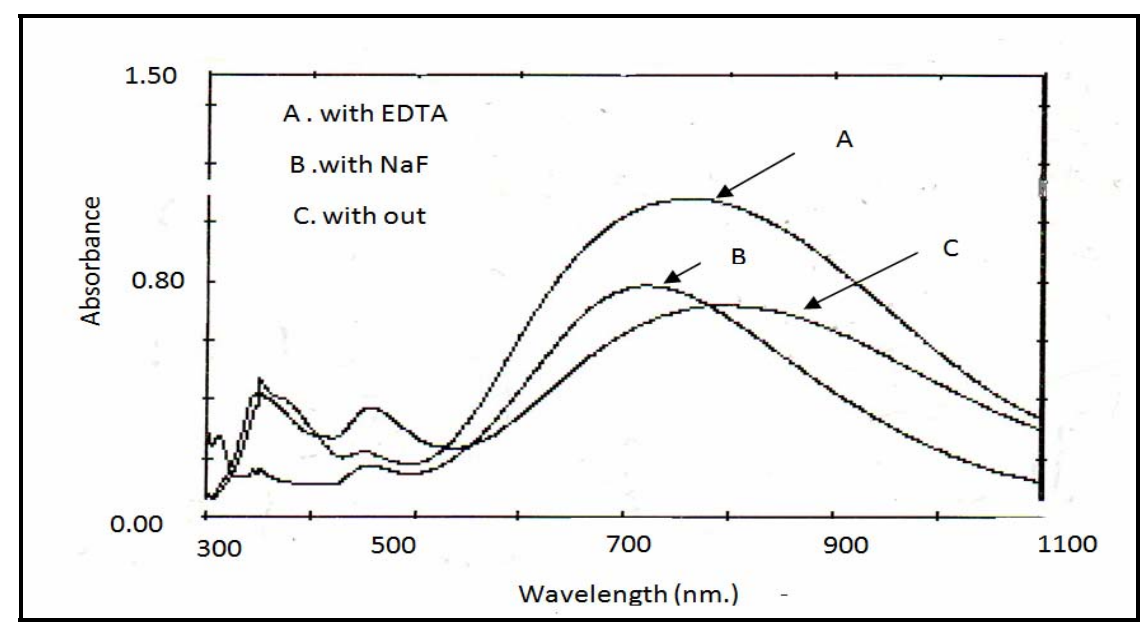

Fig. 2: The effect of EDTA and NaF on absorbance

\section{Absorption spectra}

The absorption spectra of the formed product showed a maximum absorption at $766 \mathrm{~nm}$, against the corresponding reagent blank (Fig 3).

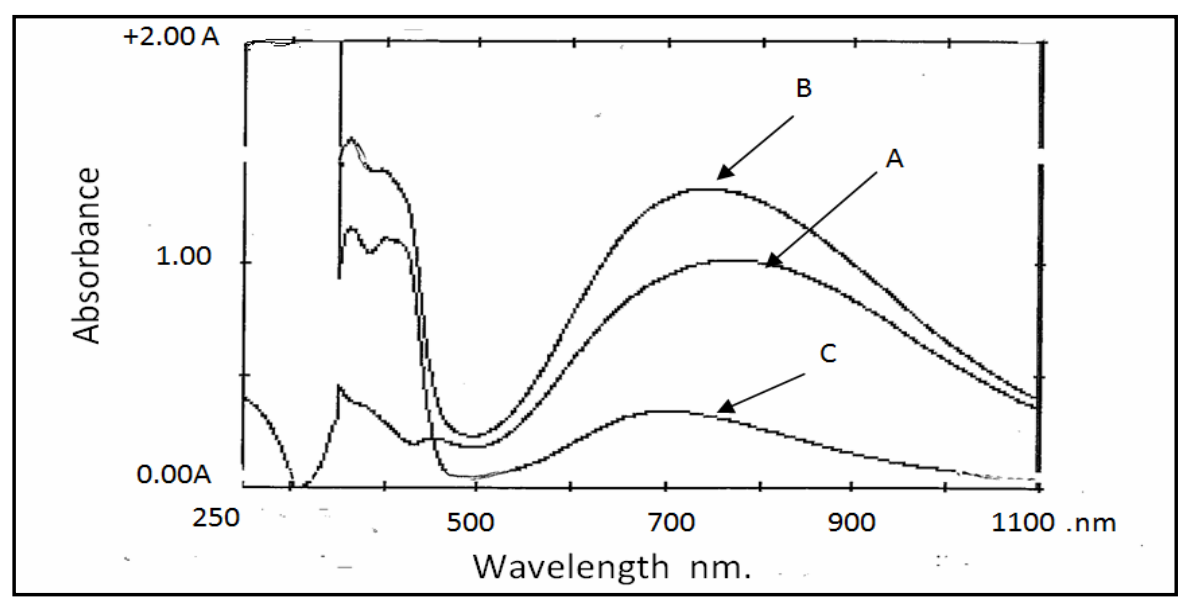

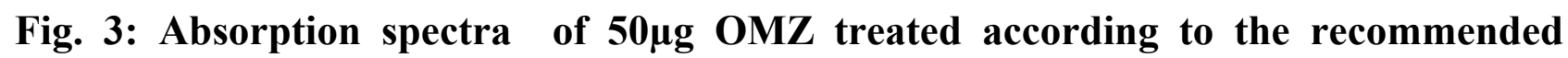
procedure and measured against (A) blank,(B) distilled water and (C) blank measured against distilled water.

\section{Accuracy and precision}

To check the accuracy and precision of the calibration curve, OMZ was determined at two different concentrations. The results shown in Table 9 indicated that the results are satisfactory.

Table 9: Accuracy and precision of the method.

\begin{tabular}{|c|c|c|c|}
\hline OMZ $\boldsymbol{\mu g}$, taken & Relative error, \% & $\begin{array}{c}\text { Relative standard } \\
\text { deviation,\% }\end{array}$ & Recovery,\%* \\
\hline 25 & +1.74 & $\pm 1.25 \%$ & $98.25 \%$ \\
\hline 50 & +2.34 & $\pm 1.98 \%$ & $97.65 \%$ \\
\hline
\end{tabular}

*Average of six determinations 


\section{The nature of the reaction product}

Job's and mole-ratio methods (Delevie, 1997) have been used in determination of reaction ratio of $\mathrm{OMZ}$ with $\mathrm{Fe}(\mathrm{III})$. The obtained results (Fig. 4) and (Fig. 5) showed that a 1:3 OMZ to $\mathrm{Fe}$ (III) ratio is obtained.

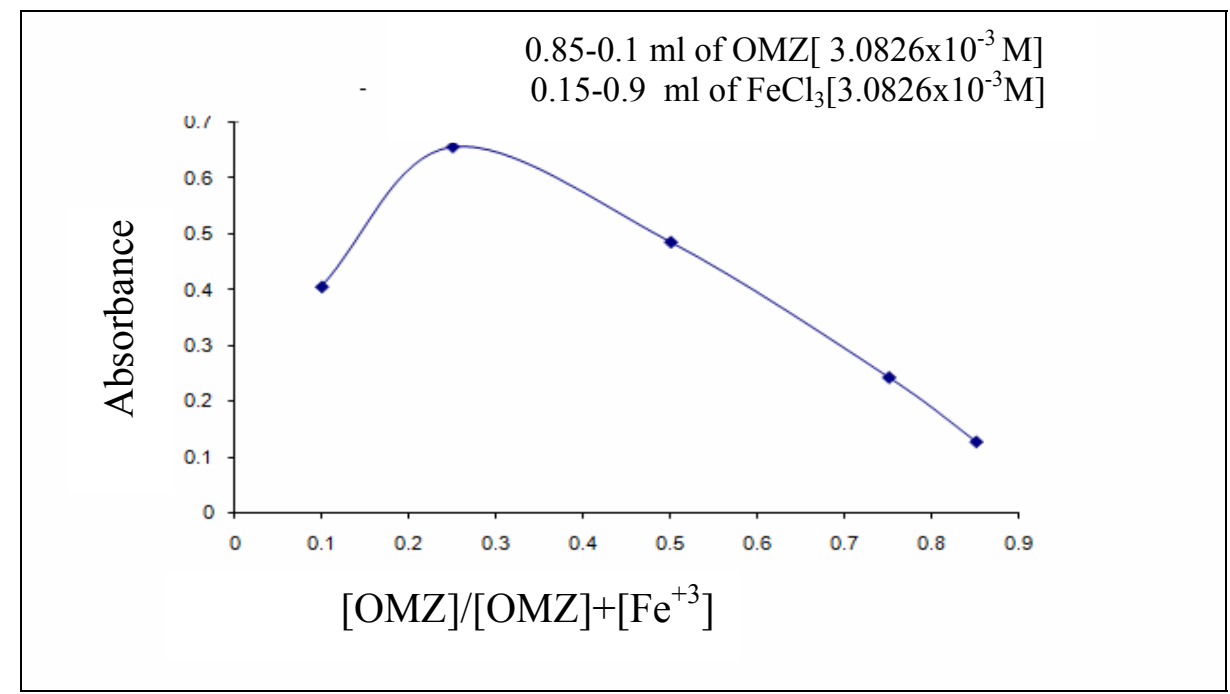

Fig. 4 : Job's plot for OMZ-Fe(III)

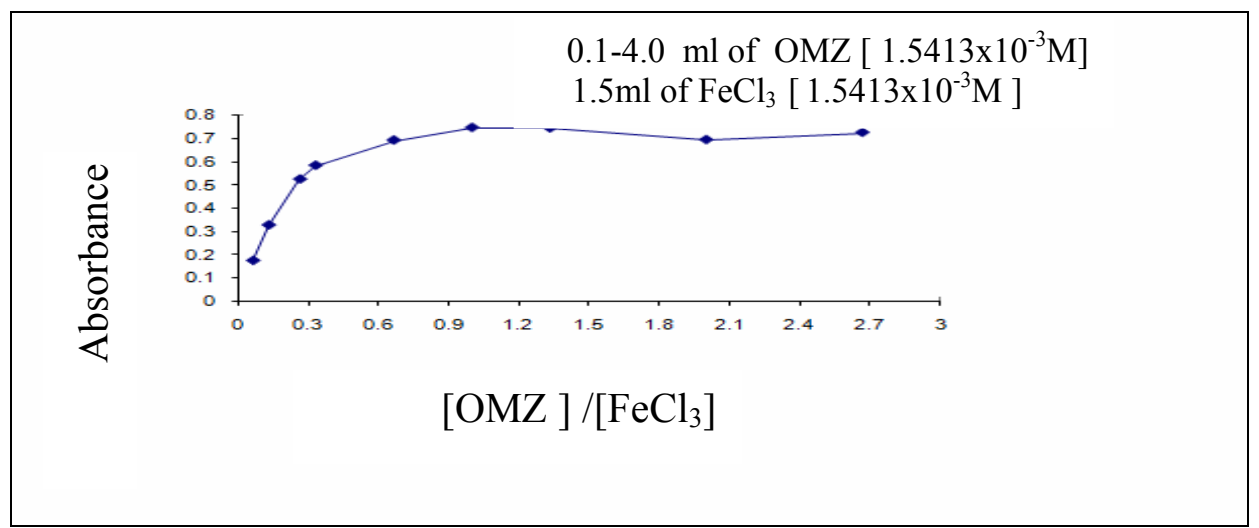

Fig. 5: Mole ratio plot for OMZ-Fe(III)

The probable mechanism of the reaction may be according to the following:<smiles>Cc1cc(C(C)(C)C)c(O)c(C)c1CC1=NC[C@@H](C(F)(F)Cl)C1</smiles><smiles>CC1=C(C(O)C2=NCCN2)C(C)C=C(C(C)C)C1=O</smiles> 
The ferrous ion produced from the above reaction was reacted with potassium ferricyanide to form the well-known product $\left(\mathrm{KFe}\left[\mathrm{Fe}(\mathrm{CN})_{6}\right]\right.$, Prussian blue) as in the following equation.

$$
\mathrm{FeCl}_{2}+\mathrm{K}_{3} \mathrm{Fe}(\mathrm{CN})_{6} \longrightarrow \mathrm{KFe}\left[\mathrm{Fe}(\mathrm{CN})_{6}\right]+2 \mathrm{KCl}
$$

\section{Effect of dilution with organic solvents}

Different organic solvents are examined in the dilution of the solution to evaluate their effects on the absorbance of the resulting colored complex and the data are shown in Table (10)

Table 10: Effect of dilution with organic solvents on the absorbance.

\begin{tabular}{|r|c|c|}
\hline \multicolumn{1}{|c|}{ Solvent } & $\max ^{\boldsymbol{\lambda}}$ & Absorbance \\
\hline Distilled water & 745 & 1.082 \\
\hline Methanol & Turbid & $\ldots \ldots$ \\
\hline Ethanol, absolute & Turbid & $\ldots \ldots$ \\
\hline N -propanol & 745 & 1.082 \\
\hline Acetone & 745 & 1.058 \\
\hline Acetic acid & 745 & 1.053 \\
\hline Formic acid & 755 & 1.024 \\
\hline DMF & 762 & 1.095 \\
\hline
\end{tabular}

Water is chosen in the subsequent experiments due to its availability, non-toxicity as well as from the sensitivity point of view.

\section{Effect of interferences}

In order to test the efficiency and selectivity of the proposed method, the effect of some foreign substances (e.g. gum acacia, glucose, lactose and starch) that usually present in dosage forms were studied by adding different amounts of foreign substances to $50 \mu \mathrm{g}$ $\mathrm{OMZ} / 10 \mathrm{ml}$.

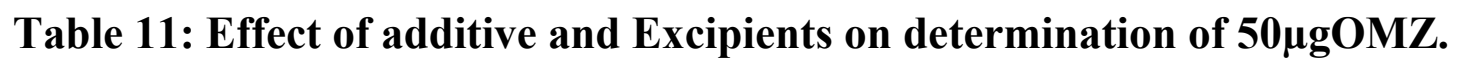

\begin{tabular}{|c|c|c|c|}
\hline \multirow[t]{2}{*}{ Excipient } & \multicolumn{3}{|c|}{ 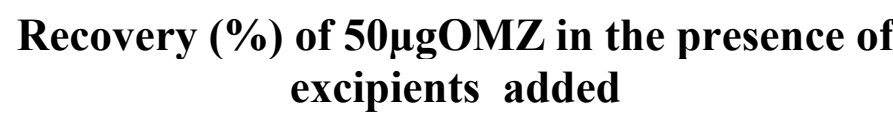 } \\
\hline & 100 & 500 & 1000 \\
\hline Gum acacia & 127.13 & 151.39 & 149.7 \\
\hline Lactose monohydrate & 98.25 & 94.15 & 89.52 \\
\hline Glucose & 109.2 & 102.6 & 109.2 \\
\hline Starch & 100.1 & 96.1 & 97.0 \\
\hline
\end{tabular}


The results indicated that gum acacia and lactose monohydrate interference at high concentration in the determination of OMZ.

\section{Application of the method}

The proposed method was successfully applied in the determination of oxymetazoline hydrochloride in pharmaceutical preparation (nasal drops), the results which are shown in Table 12 indicate that good recoveries are obtained.

Table 12: Analytical application.

\begin{tabular}{|c|c|c|c|}
\hline Drug & $\boldsymbol{\mu g}$ OMZ/10ml & Recovery*\% & RSD\% \\
\hline $\begin{array}{c}\text { Oxymet } \\
\mathbf{( 0 . 0 5 \% )}\end{array}$ & 25 & 98.25 & \pm 1.272 \\
\cline { 2 - 4 } $\begin{array}{c}\text { Pharonia- } \\
\text { Egypt }\end{array}$ & 50 & 97.65 & \pm 1.982 \\
\hline
\end{tabular}

* Average of six determinations

Note : Added $0.004 \mathrm{~g}$ of $\mathrm{NaH}_{2} \mathrm{PO}_{4}$ and $0.004 \mathrm{~g}$ of $\mathrm{Na}_{2} \mathrm{HPO}_{4}$ to a standard solution.

Evaluation of the proposed method:

According to the difficulties of using the standard method for the determination of OMZ which includes potentiometric titration, so standard addition method was applied in order to prove that the proposed method is free from interference in the determination of OMZ in pharmaceutical preparations.( Table 13 and Fig. 6).

Table 13: The results of standard addition method

\begin{tabular}{|c|c|c|c|}
\hline Drug & $\begin{array}{c}\boldsymbol{\mu g} \text { OMZ } \\
\text { present/ml }\end{array}$ & $\begin{array}{c}\boldsymbol{\mu g ~ O M Z} \\
\text { measured/10ml }\end{array}$ & Recovery\% \\
\hline Oxymet 0.05\% & 5 & 4.82 & $96.45 \%$ \\
\cline { 2 - 4 } Pharaonia-Egypt & 6.5 & 6.31 & $97.18 \%$ \\
\hline
\end{tabular}

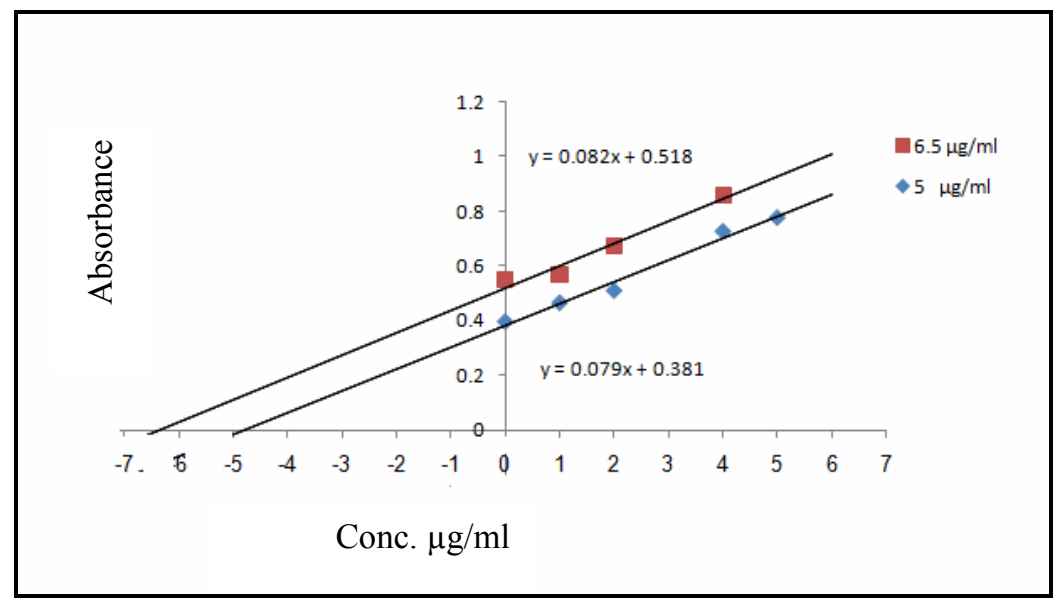

Fig. 6: Graph of standard addition plot for the determination of OMZ in oxymet. 
The result in Table 13 and Fig. 6 indicated that the proposed method can be used to the determination $\mathrm{OMZ}$ in pharmaceutical preparation with a satisfactory result.

\section{Comparison of the methods}

Table (14) shows the comparison between some of analytical variables for the present method with that of other literature spectrophotometric methods.

Table 14: Comparison of the methods.

\begin{tabular}{|c|c|c|c|}
\hline Variable & $\begin{array}{l}\text { Present } \\
\text { Method }\end{array}$ & $\begin{array}{c}\text { Literature method } \\
\text { (Al-Sabha and } \\
\text { Rasheed, 2011) }\end{array}$ & $\begin{array}{l}\text { Literature method } \\
\text { (Zakaria, 2011) }\end{array}$ \\
\hline Reagent & $\begin{array}{c}\text { Potassium } \\
\text { ferricyanide }\end{array}$ & 1,10-Phenanthroline & 4-Aminoantipyrine \\
\hline Temperature $\left({ }^{\circ} \mathrm{C}\right)$ & 50 & 70 & 70 \\
\hline $\mathrm{pH}$ & 2.70 & 3.82 & 13.15 \\
\hline $\begin{array}{l}\text { Molar absorptivity } \\
\left(1 . \mathrm{mol}^{-1} \cdot \mathrm{cm}^{-1}\right)\end{array}$ & $5.07 \times 10^{4}$ & $5.74 \times 10^{4}$ & $5.34 \times 10^{4}$ \\
\hline$\lambda_{\max }(\mathrm{nm})$ & 766 & 510 & 480 \\
\hline Recovery (\%) & $98.25-97.65$ & 100.53 & $98.33-100.33$ \\
\hline $\operatorname{RSD}(\%)$ & $1.27-1.98$ & $0.72-1.6$ & $0.36-1.58$ \\
\hline Beer's law range $\mu \mathrm{g} / \mathrm{ml}$ & $0.5-12.5$ & $0.1-7$ & $0.36-1.58$ \\
\hline
\end{tabular}

The results in Table 14 indicated that the suggested method was sensitive and accurate.

\section{CONCLUSION}

The proposed method for the determination of OMZ in pharmaceutical formulation is simple, sensitive, accurate and precise. The method is based on oxidation - reduction between OMZ and Fe (III), then the subsequent reaction of librated Fe (II) with potassium ferricyanide to form Prussian blue complex which is water soluble, stable and shows a maximum absorption at $766 \mathrm{~nm}$. The proposed method has been applied successfully to the determination of the intended compound in its pharmaceutical formulation (nasal drop)

\section{REFERENCES}

AL-Sabha, T. N.; Rasheed, B. A. (2011). Spectrophotometric determination of oxymetazoline hydrochloride based on the oxidation reaction. Jordan J. Chim., 56(4), 403-411.

AL-Neaimy, U. I. (2006). The use of 3,5-dinitrosalicylic acid in spectrophotometric determination of organic and drug compounds. Ph. D., Thesis, Mosul University., pp.82-104.

"British Pharmacopoeia on CD-ROM" (2007). 5th ed. System Simulation Ltd, The Stationary Office, London. 
Delevie, R. (1997). 'Principles of Quantitative Chemical Analysis". McGraw-Hill, Internation Ed., Singapore, 498 p.

Garcia-Campana, A. M.; Sendra, J. M. ; Vargas, M. P.; Baeyens, W.R. ; Zhang, X. (2004). Flow injection analysis of oxymetazoline hydrochloride with inhibited chemiluminesscent detection. Anal. Chim. Acta, 516, 245-249.

Hayes, F.J.; Beaker, T. R.; Dobson, R. M.; Tueda, M. S. (1995). Rapid liquid chromatographic -mass spectrometric assay for oxymetazoline in whole rat blood. J. Chromatogr. A, 692, 73-81.

Hoffmann, T.; Thompson R.; Seifert J. (1989). Determination of the nasal decongestant, oxymetazoline hydrochloride, in pharmaceutical formulations by HPLC. Drug development and Industrial Pharmacy, 15(5), 743-757.

Hong, Y.Y. (2009). Content determination of oxymetazoline hydrochloride spray by HPLC. J. Strait Pharm.【 DOI】: CNKI:SUN:HAIX.0.2009-09-017

http://www.wikikpedia.org./wiki/oxymetazoline, (2008).

Issa, Y. M.; Zayed, S. I. (2004). Construction and analytical application of plastic membrance electrode for oxymetazoline hydrochloride. Anal. Sci., 20, 297-300.

Sane, R.; Joshi, L. ; Latage, K.; Kothurkar, R. ; Bhate, V. (1990). High performance liquid chromatographic determination of oxymetazoline hydrochloride from nasal drop. Ind. J .Pharm. Sci.,52(1), 38-39.

Sankar, D. G.; Sastry, C. S. P. ; Reddy, M. N. ; Aruna, M. (1988). Spectrophotometric determination of adrenergic agents using iron (III) and 2,4,6-tris(2-pyridyl)-striazine. Ind. J. Pharm. Sci, 50,178-180.

Sankar, D. G.; Sastry, C. S. P. ; Ready , M. N.; Akuna, M. (1987). Spectrophotometric determination of some a drenergic agents using 2,6-dichloroquinone-chlorimide. Ind. J. Pharm. Sci., 49, 69-71.

Shingbal, D .M. ; Naik, S. D. (1983). Spectrophotometric determination of oxymetazoline hydrochloride. East Pharm., 26, 201-202.

Stanisz, B.; Nowinski, W. (2000). Determination of oxymetazoline hydrochloride and decomposition products by high -performance liquid chromatography. Acta Pol. Pharm. Drug Research, 57(6), 339-401.

Sudsakom, S.; Kaplan, L.; Williams, D. A. (2006). Simultaneous determination of triamcinolone acetonide and oxymetazoline hydrochloride in nasal spray formulations by HPLC. J. Pharm. Biomed. Anal. 40(5), 1273-80.

"USP Pharmacopoeia on CD-ROM", (2009). The United States Pharmascopeial Convention.

Wang, N.N.; Shao Y.Q.; Tang, Y.H.; Yin, H.P.; Wu, X.Z. (2009). Flow injection chemiluminescen method. Biological J. Chem. Iluminescence, 24, 178-182.

Zakaria, S. A. (2011). Spectrophotometric determination of oxymetazoline hydrochloride via oxidative coupling reaction with 4-aminoantipyrine in the presence of potassium periodate. Raf. J. Sci. , 22 ( 4), 97-108. 